1 Long-term effects of pig slurry on barley yield and $\mathbf{N}$ use efficiency under semiarid

2

3

4

5

6

7

8

$9 \quad{ }^{*}$ Corresponding author. Tel.: +34 917452500 Ext. 950191

10 E-mail address: c.plaza@ica.csic.es (C. Plaza)

\section{Mediterranean conditions}

Diana Hernández, Alfredo Polo, César Plaza*

Serrano 115 bis, 28006 Madrid, Spain

8

Instituto de Ciencias Agrarias, Consejo Superior de Investigaciones Cientificas, 


\section{Abstract}

13 Intensive pig farming is a relevant economic activity in Mediterranean areas, which

14 generates large amounts of pig slurry (PS) as a by-product. Pig slurry represents a

15 valuable resource for low-fertility Mediterranean soils, capable of supplying organic

16 matter and plant nutrients, particularly N. The cumulative and residual effects of PS on

17 winter barley (Hordeum vulgare L.) yield and $\mathrm{N}$ use efficiency were investigated in a

18 seven-year field experiment under semiarid Mediterranean conditions. Treatments

19 included five rates of PS ranging from 30 to $150 \mathrm{~m}^{3} \mathrm{ha}^{-1}$ applied either every year or

20 only once at the beginning of the experiment, an annual mineral $\mathrm{N}$ fertilization

21 (traditional in the study area), and a control with no fertilization. Plant-available $\mathrm{N}$

22 content in soils after harvest increased with the annual application of PS with respect to

23 the mineral fertilization and the control treatment, especially in dry years. Yearly

24 variations in water availability also shaped the response of barley to PS fertilization. In

25 general, the annual application of PS affected positively grain yield and biomass

26 production. Residual effects were evident for the second and third barley crop.

27 Cumulative $\mathrm{N}$ uptake by the barley crop increased with increasing the rate of PS (up to

$28120 \mathrm{t} \mathrm{ha}^{-1}$ ), while $\mathrm{N}$ use efficiency decreased, which suggested an increasing risk of

29 leaching and contamination of ground water. As a whole, our data indicate that the

30 annual application of $30 \mathrm{~m}^{3} \mathrm{ha}^{-1}$ of PS (equivalent to an average of $67 \mathrm{~kg} \mathrm{~N} \mathrm{ha}^{-1}$ ) may

31 result in barley yields similar to those obtained with the traditional mineral fertilization,

32 while safely adhering to European regulations for the use of $\mathrm{N}$ in agriculture. The

33 application of PS at rates higher than $60 \mathrm{~m}^{3} \mathrm{ha}^{-1}$ may result in better yields, but also in

34 significantly lower $\mathrm{N}$ use efficiency and a higher potential environmental impact. 
36 Keywords: Hordeum vulgare L.; Mineral fertilization; Liquid manure; N mineralization;

$37 \quad \mathrm{~N}$ immobilization; $\mathrm{N}$ uptake.

38 


\section{Introduction}

Intensive pig farming has developed significantly in Spain in the last decades. According to current data (MARM, 2010), Spain is the second largest producer of pigs in the European Union (after Germany) with more than 25 million heads. This activity is estimated to generate more than 65 million $\mathrm{m}^{3}$ of pig slurry (PS) per year. Since intensive pig farming is concentrated in certain areas, an effort to adequately manage PS must be done to avoid environmental and health hazards.

The application of PS to agricultural soils has the benefit of providing organic matter (OM) and plant nutrients, especially N (Sánchez and González, 2005), and hence may help reduce the use of mineral $\mathrm{N}$ fertilizers. Most $\mathrm{N}$ in PS is contained in inorganic forms, mainly as $\mathrm{NH}_{4}{ }^{+}$(Sánchez and González, 2005). The organic N applied with PS is incorporated into the soil OM pool and can be converted to $\mathrm{NH}_{4}{ }^{+}$through mineralization or absorbed by soil microorganisms for their growth. Inorganic $\mathrm{N}\left(\mathrm{NH}_{4}{ }^{+}\right.$ and $\mathrm{NO}_{3}^{-}$) can be taken up by the plants or immobilized by the microbial biomass.

When microbial growth is limited by organic $\mathrm{C}$, net $\mathrm{N}$ mineralization occurs, whereas immobilization occurs to a greater extent when microbial growth is limited by $\mathrm{N}$ (Bardgett, 2005). Inorganic N in PS-amended soils not taken up by the plants and not immobilized by the microbial biomass may be lost from the soil through denitrification, volatilization, and leaching processes. Thus, excessive or inappropriate application of PS to agricultural soils may seriously endanger air and ground water quality (Díez et al., 2004; Vallejo et al., 2004; Misselbrook et al., 2005).

Plant-available $\mathrm{N}$ in soils fertilized with mineral and organic fertilizers can differ markedly (Gutser et al., 2005). While plants can take up most of the $\mathrm{N}$ added with mineral fertilizers during the year of application (Gutser et al., 2005), a large part of the 
64 mineral $\mathrm{N}$ applied with PS can be immobilized by microorganisms shortly after its

65 incorporation into the soil during the degradation of readily available organic compounds also added with the PS (Sørensen and Amato, 2002); further, part of the PS-

67 derived $\mathrm{NH}_{4}{ }^{+}$can be fixed on clay surfaces or between clay layers. As a result, $\mathrm{N}$

68 utilization by crops in the year of application may be relatively small. However, part of

69 the immobilized $\mathrm{N}$ can be mineralized in subsequent years, releasing $\mathrm{N}$ that becomes

70 available for plant uptake and thus inducing residual effects generally not accounted for

71 in short-term experiments (Sørensen and Amato, 2002). When organic fertilizers are

72 used repeatedly, residual effects accumulate, $\mathrm{N}$ availability increases, and crop

73 responses may be significantly affected (Schröder et al., 2005).

74 A number of studies in the literature have evaluated the effects of PS on crops (Petersen, 75 1996; Nicholson et al., 1999; Mooleki et al., 2002, 2004; Edmeades, 2003; Schröder et

76 al., 2005, 2007). However, the available information on crop responses to PS

77 fertilization under Mediterranean conditions is scarce (Daudén and Quílez, 2004; Yagüe 78 and Quílez, 2010). Mediterranean areas are characterized by a warm and dry climate, 79 with erratic and scarce precipitations, which renders water availability the main limiting 80 factor for crop production. Accordingly, soils feature low OM contents due to high 81 mineralization rates enhanced by high temperatures. Some agricultural practices, such 82 as intensive tillage and harvesting of crop residues, often lead to an intensification of the 83 loss of soil OM, resulting in soils with low fertility levels and high vulnerability to 84 erosion and degradation. In consequence, managing soil OM and plant nutrients properly through the use of organic amendments, such as PS, is especially important in

86 Mediterranean agricultural areas (Zdruli et al., 2004).

87 In this work, a seven-year field experiment was used with the aim of evaluating the 88 response of winter barley (Hordeum vulgare L.) to PS fertilization under Mediterranean 
rain-fed conditions. Cumulative (annual applications) and residual (only one initial addition) effects of five increasing rates of PS (from 30 to $150 \mathrm{~m}^{3} \mathrm{ha}^{-1}$ ) on plantavailable $\mathrm{N}$, crop yield, $\mathrm{N}$ uptake, and $\mathrm{N}$ use efficiency were assessed to improve our fundamental knowledge of the potential of this material as a $\mathrm{N}$ source; this is essential for proper recommendations regarding application rates while reducing the risks of soil, water, and air contamination. In Spain, barley grain yield in rain-fed conditions is estimated to vary between an average of $2000 \mathrm{~kg} \mathrm{ha}^{-1}$ in arid regions and an average of $5300 \mathrm{t} \mathrm{ha}^{-1}$ in humid regions; hence the average optimum $\mathrm{N}$ rate can vary greatly, between 50 to $140 \mathrm{~kg} \mathrm{~N}$ ha $^{-1}$ based on the assumption that barley requires an average of $25 \mathrm{~kg}$ of $\mathrm{N}$ to produce $1000 \mathrm{~kg}$ of grain (López, 2010). Here a mineral fertilization of about $100 \mathrm{~kg} \mathrm{~N} \mathrm{ha}^{-1}$, which is traditional in the study area, and a control treatment with no fertilization were used as references for comparison.

\section{Materials and methods}

\subsection{Site, experimental design, soil, and pig slurry}

A field plot experiment was conducted on rain-fed winter barley (var. Reinette) over seven seasons from 1997-1998 to 2003-2004 in the experimental farm "La Higueruela" of the Spanish National Research Council (CSIC), located in Santa Olalla, Toledo province, Spain. The site is characterized by a continental semiarid climate with an annual rainfall of $487 \mathrm{~mm}$ and an average annual temperature of $14{ }^{\circ} \mathrm{C}$. Monthly mean temperatures and monthly precipitation during the experiment are shown in Fig. 1. At the beginning of the first season (mid-October, 1997), plots $(10 \mathrm{~m} \times 8 \mathrm{~m})$ were 
amended with PS at rates of 30 (PS30), 60 (PS60), 90 (PS90), 120 (PS120), and 150 (PS150) $\mathrm{m}^{3} \mathrm{ha}^{-1}$ before barley sowing (early November). Six plots were set up for each rate of PS. From the second season on, three plots of each PS rate were left unamended in order to study the residual effects of PS fertilization over the rest of the study period, whereas the other three plots were amended with PS at the same rate in October of every year until 2003 in order to study the cumulative effects. To compare with the PS treatments, a mineral fertilization (MF) traditionally used in the area was annually applied in triplicate as $400 \mathrm{~kg} \mathrm{ha}^{-1}$ of N-P-K $15-15-15$ prior to sowing and $150 \mathrm{~kg} \mathrm{ha}^{-1}$ of $\mathrm{NH}_{4} \mathrm{NO}_{3}$ (equivalent to $53 \mathrm{~kg} \mathrm{ha}^{-1} \mathrm{y}^{-1}$ of $\mathrm{N}$ ) in mid-March at the beginning of tillering. A control treatment with three replicates with no fertilization was also included in the experimental design (C). A scheme of the field plot experimental is shown in Fig. 2. For the sake of clarity, crop seasons are denoted herein by the year of the crop harvest (from 1998 to 2004).

The soil of the experiment was classified as Typic Haploxeralf (Soil Survey Staff, 2003). The main characteristics of the top layer $(0-15 \mathrm{~cm})$ measured at the beginning of the experiment were the following: sandy loam texture (sand, $590 \mathrm{~g} \mathrm{~kg}^{-1}$; silt, $220 \mathrm{~g} \mathrm{~kg}^{-}$ 1; clay, $\left.190 \mathrm{~g} \mathrm{~kg}^{-1}\right)$; $\mathrm{pH}\left(\mathrm{H}_{2} \mathrm{O}\right), 5.8$; electrical conductivity (EC), $0.06 \mathrm{dS} \mathrm{m}^{-1}$; Kjeldahl $\mathrm{N}$ content, $1.2 \mathrm{~g} \mathrm{~kg}^{-1} ; \mathrm{NH}_{4}{ }^{+}-\mathrm{N}, 86.2 \mathrm{mg} \mathrm{kg}^{-1} ; \mathrm{NO}_{3}{ }^{-}-\mathrm{N}, 19.9 \mathrm{mg} \mathrm{kg}^{-1}$; total organic C (TOC), $13.2 \mathrm{~g} \mathrm{~kg}^{-1}$; available $\mathrm{P}, 60 \mathrm{mg} \mathrm{kg}^{-1}$; and available $\mathrm{K}, 491 \mathrm{mg} \mathrm{kg}^{-1}$. These values are indicative of slight acidic $\mathrm{pH}$, low $\mathrm{EC}$ and TOC content, medium available $\mathrm{N}$ and $\mathrm{P}$ contents, and high K content (Cadahía and Lucena, 1998; López and Grau, 2004). The pig slurry was collected every year from a pig-breeding farm which employed a closed-cycle production system. The slurry in the storage pit was stirred the day of application and pumped to a tanker equipped with a splash plate. The PS was applied by surface spreading and immediately incorporated by disking into the top $15 \mathrm{~cm}$ of soil. 
139 Samples of PS were taken from the tank. The main characteristics of the PS applied 140 each year are listed in Table 1.

141

142

2.2. Sampling and analysis of plant and soil

143

144 Every year in late June (from 1998 to 2004), soon after grain maturity was reached, the 145 above-ground barley biomass (AGB) of six 0.5-m-long rows, equivalent to an area of $1460.45 \mathrm{~m}^{2}$, was collected randomly from each plot. The plant samples were weighed, 147 threshed, and then the grain weighed. Sub-samples of grain and straw were ground to 148 pass a $0.5-\mathrm{mm}$ sieve and analyzed for total $\mathrm{N}$ by inductively coupled plasma-atomic emission spectroscopy (PerkinElmer ICP/5500, Waltham, MA) after nitric-perchloric acid digestion.

151 Soon after harvest, soil samples were prepared by mixing ten surface $(0-15 \mathrm{~cm})$ soil 152 subsamples randomly collected from each plot. Plant-available $\mathrm{N}\left(\mathrm{NH}_{4}^{+}-\mathrm{N}\right.$ plus $\mathrm{NO}_{3}^{-}-$ $153 \mathrm{~N}$ ) content was determined by extraction with $2 \mathrm{M} \mathrm{KCl}$ (soil to extractant ratio of 1:10) and colorimetry (Keeney and Nelson, 1982) with an automated analyzer (Technicon AutoAnalyzer AAII, Buffalo Grove, IL).

\subsection{Parameters of $N$ use efficiency and statistics}

Nitrogen uptake by the barley crop was estimated as the sum of grain plus straw $\mathrm{N}$ uptake, which is considered to be a good indicator of the total plant N uptake (Mooleki et al., 2002). Grain and straw uptake was calculated by multiplying $\mathrm{N}$ concentrations by 162 yields.

163 Cumualative $\mathrm{N}$ use efficiency (NUE) for each treatment ( $\mathrm{t}$ ) and year (i) was calculated 
$165 N U E_{t, i}(\%)=\left(\sum_{i=1998}^{2004} C N U_{t, i}-\sum_{i=1998}^{2004} C N U_{C, i}\right) / \sum_{i=1998}^{2004} C N A_{t, i}$

166 where $\mathrm{CNU}$ is the cumulative $\mathrm{N}$ uptake by the crop on the treated plots, $\mathrm{CNU}_{\mathrm{C}}$ is the

167 cumulative $\mathrm{N}$ uptake by the crop on the control plots, and CNA is the cumulative

168 amount of $\mathrm{N}$ applied with the PS or MF treatment (Mooleki et al., 2002).

169 Agronomic efficiency (AE) was calculated as

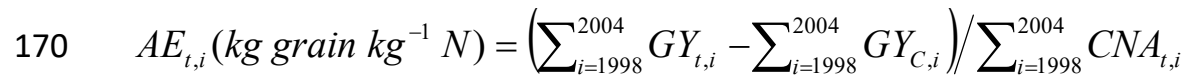

171 where $\mathrm{GY}$ and $\mathrm{CY}_{\mathrm{C}}$ are the cumulative grain yields on the treated and control plots,

172 respectively (Mengel and Kirkby, 2001).

173 Finally, to compare the N availability from the PS amendment with that from the

174 mineral fertilization, we calculated the apparent mineral-fertilizer-N equivalents (MFE)

175 according to Gutser et al. (2005) as

176

$\operatorname{MFE}_{t, i}(\%)=\left(\sum_{i=1998}^{2004} C N U_{t, i}-\sum_{i=1998}^{2004} C N U_{C, i}\right) /\left(\sum_{i=1998}^{2004} C N U_{M F, i}-\sum_{i=1998}^{2004} C N U_{C, i}\right)(3)$

Statistical calculations were performed with the SPSS 18.0 software for Windows

(Statistical Product and Service Solutions Inc., Chicago, IL). Data from dependent

measures (available $\mathrm{N}$, grain yield, AGB, grain $\mathrm{N}$ content, $\mathrm{N}$ uptake, NUE, $\mathrm{AE}$, and

MFE) were subjected to one-way ANOVA within each year. Cumulative and residual

PS treatments were analyzed independently and compared to C and MF treatments. The used for mean separation.

\section{Results}




\subsection{Plant-available $N$}

In general, plant-available $\mathrm{N}$ contents in the top layer $(0-15 \mathrm{~cm})$ of the $\mathrm{C}$ and MF soils

after harvest were similar to each other and tended to decrease over the years (Fig. 3). In 1998 and 2001 (693 and $676 \mathrm{~mm}$ of precipitation, respectively), the available $\mathrm{N}$ content of the PS-amended soils (except PS150) did not differ significantly from those of the C and MF soils. By contrast, in 2002, 2003, 2004, and especially in 1999 and 2000 (552, $489,563,328$, and $410 \mathrm{~mm}$ of precipitation), differences in available $\mathrm{N}$ content between the PS soils and the MF and $\mathrm{C}$ soils were more evident. Compared to $\mathrm{C}$ and $\mathrm{MF}$, no significant residual effects of PS on available $\mathrm{N}$ were detected.

\subsection{Grain yield and above-ground biomass}

Barley grain yield and AGB as affected by the different treatments are shown in Fig. 4.

The extent of the crop response to PS application fluctuated over the years. In the first season (1998), with high precipitation in November and May, grain yields for the PS90 and PS120 plots were larger than for the MF treatment; however, in 1999, when precipitation was low, no differences between PS and MF were found. In 2000, the PS treatments did not differ significantly from C, whereas in 2001, which was characterized by high precipitation in autumn and winter but low in spring, PS90 yielded better results than $\mathrm{C}$ and MF. In 2002, with dry winter and rainy spring, no significant differences were found between treatments. In 2003, exceptionally high temperatures and low precipitation in spring led to very low grain yields for $\mathrm{C}, \mathrm{MF}$, and the treatments with

211 low PS rates; PS120 and PS150 resulted in significantly higher yields than C and MF.

212 In 2004, which was characterized by a slightly high precipitation in spring, grain yields 
213 were higher for the PS treatments (except for PS30) than for C and MF.

214 In 1999, the single applications of PS did not cause significant residual effects on grain 215 yield with respect to the $\mathrm{C}$ treatment. In 2000 (i.e., third crop after the PS application), 216 however, positive residual effects were observed for rates equal or higher than $60 \mathrm{~m}^{3} \mathrm{ha}^{-}$

217 1, although not significant with respect to MF. In the next years, the residual effects of

218 PS diminished and no significant differences were found compared to C.

219 In general, the trends observed for AGB as affected by PS additions were similar to 220 those observed for grain yields. From 1998 to 2000, no annual PS treatment was significantly different from MF. In 2001, only PS90 exhibited higher AGB than MF. In the last three years, PS120 and PS150 resulted in higher AGB than C and MF. With respect to $\mathrm{C}$, some significant positive effects of the single applications of PS were observed on the AGB harvested in 1999 and 2000.

Cumulative grain yield and AGB production after the seven years of experiment are shown in Table 2. Total grain yield and AGB were higher for the plots amended annually with PS than for the MF and C plots, and the differences increased significantly with increasing the PS rate up to $120 \mathrm{~m}^{3} \mathrm{ha}^{-1}$. By contrast, total grain yield and AGB production for the plots amended once with PS were similar to those obtained with the $\mathrm{C}$ treatment and significantly smaller than those for the MF plots.

\subsection{Grain $N$ content and plant $N$ uptake}

In general, $\mathrm{N}$ content of grain and $\mathrm{N}$ uptake by the plants were similar or higher for the annual PS treatments than for MF and $\mathrm{C}$, and tended to increase with increasing the rate of PS (Fig. 5). Residual effects of the single applications of PS on grain N content and plant $\mathrm{N}$ uptake disappeared after 2000. 
238 Highly significant positive linear relationships between the cumulative $\mathrm{N}$ uptake by the 239 barley crops harvested since 1998 until 2004 and the cumulative $\mathrm{N}$ applied were found 240 for MF and especially for the PS treatments (Fig. 6). The slope of the linear regression

241 (i.e., ratio between cumulative $\mathrm{N}$ uptake and $\mathrm{N}$ applied) was $0.946 \mathrm{~kg} \mathrm{~N} \mathrm{~kg}^{-1}$ for MF and

242 ranged from $1.433 \mathrm{~kg} \mathrm{~N} \mathrm{~kg}^{-1}$ for PS30 to $0.471 \mathrm{~kg} \mathrm{~N} \mathrm{~kg}^{-1}$ for PS 150 , tending to

243 decrease with increasing the PS rate. A slope lower than 1 indicates a smaller $\mathrm{N}$ uptake

244 by barley relative to the amount of $\mathrm{N}$ applied and thus a long-term over-fertilization.

245 Based on the $\mathrm{N}$ uptake by barley and the amount of $\mathrm{N}$ supplied, an excess of 778 and $2461246 \mathrm{~kg} \mathrm{ha}^{-1}$ of $\mathrm{N}$ was estimated in the soils annually amended with 120 and $150 \mathrm{~m}^{3} \mathrm{ha}^{-}$ 247 , respectively.

248

249

\subsection{Parameters of $N$ use efficiency}

250

251

252

253

254

255

256

257 applied annually. With the exception of PS30 in 2003 and 2004, the AE values for the single applications of PS were larger than the corresponding values for the annual PS treatments. 
In general, the MFE values tended to increase with increasing rate of PS annually applied up to $120 \mathrm{~m}^{3} \mathrm{ha}^{-1}$ and with increasing number of applications, reaching values much higher than $100 \%$ (Fig. 7). For the plots amended only once with PS, MFE tended to increase with increasing the PS rate, up to about 100\% for PS120 and PS150.

\section{Discussion}

Continuous cropping caused plant-available $\mathrm{N}$ to decrease over the years in the $\mathrm{C}$ and MF soils, but not in the soils amended annually with high rates of PS. Differences between the PS and the MF and $\mathrm{C}$ treatments in $\mathrm{N}$ accumulation in soil increased with increasing the PS rate and appeared to be more evident in dry seasons, probably due to water-limited processes of $\mathrm{N}$ losses by leaching and $\mathrm{N}$ uptake by the crop (Pardo et al., 2009).

In general, barley response in terms of grain yield, biomass production, and grain $\mathrm{N}$ content was positively affected by the annual application of PS. In agreement with Thomsen and Sørensen (2006), moderate or high applications of PS enhance crop N uptake compared with MF. Previous studies also suggest that that suitable PS rates can result in satisfactory crop yields, similar to those obtained with mineral fertilizers (Petersen, 1996; Nicholson et al., 1999; Mooleki et al., 2002; Daudén and Quílez, 2004; Díez et al., 2004). In the literature, there are also data from long-term experiments indicating that animal manures only influenced soil productivity when large inputs were applied over many years (Edmeades, 2003).

In general agreement with previous results (Daudén and Quílez, 2004; Schröder et al., 2007), PS exhibited a significant residual agronomic value, which was evident even two 
years after the amendment and can be attributed to the slow release of $\mathrm{N}$ immobilized

289 shortly after the first PS application. According to Sørensen and Amato (2002), the contribution of immobilized $\mathrm{N}$ released as mineral $\mathrm{N}$ to crops in PS-amended soils is relatively low, but steady for 2-3 years after the amendment, which greatly determines the residual fertilizer value of PS.

The crop response to PS was found to be affected by the temperature and precipitation distribution during the crop season. When temperature and precipitation distribution was adequate for crop development, differences in crop response between PS treatments and $\mathrm{C}$ and $\mathrm{MF}$ treatments were not as evident as in years with unfavorable conditions. When water supply is adequate at the end of the winter, high levels of $\mathrm{N}$ can overstimulate biomass production and favor cereal tillering (Pardo et al., 2009). However, if water is in short supply at the end of the crop period, the grain may be not filled, which may result low yields (Angás et al., 2006). High plant $\mathrm{N}$ uptake and low yield may be indicative of luxury consumption (Angás et al., 2006).

In 2003, C, MF, and the residual PS treatments exhibited high weed (mainly Lolium rigidum L.) emergence, while cumulative plots were hardly affected. Weed emergence due to the continuous monoculture crop system is known to affect crop productivity, especially in non-irrigated low-fertility soils (Díaz-Ambrona and Mínguez, 2001). Petersen (2003) also found that barley was able to compete adequately with weeds for 307 nutrients in soils repeatedly amended with PS.

308 The results obtained indicated that cumulative $\mathrm{N}$ applied with the mineral fertilizer and 309 PS at rates of 30 and $60 \mathrm{tha}^{-1}$ matched well the cumulative $\mathrm{N}$ uptake by the barley 310 crops. With increasing the rate and number of PS additions, the $\mathrm{N}$ applied exceeded 311 increasingly the barley $\mathrm{N}$ uptake. In agreement with Mooleki et al. (2002), increased 312 annual application rates of PS do not necessarily result in enhanced crop responses in 
313 terms of $\mathrm{N}$ uptake and grain yield (i.e, high NUE and AE) because plant capacity to

314 assimilate $\mathrm{N}$ and produce grain is limited; also significant losses of $\mathrm{N}$ after PS

315 application may occur.

316 In our study, the mineral $\mathrm{N}$ content measured in the soils amended annually with high

317 PS rates after seven barley crops was relatively low. This suggests that relatively large

318 amounts of the mineral $\mathrm{N}$ applied with PS not taken up by the crops were immobilized

319 by soil microorganisms and/or lost by volatilization and leaching processes. Annual

320 application of high rates of PS was found to stimulate soil OM mineralization processes

321 in the experiment examined in this study (Plaza et al., 2002); $\mathrm{N}$ mineralization was also

322 found to occur at a greater rate that immobilization by means of an incubation

323 experiment (Plaza et al., 2005). Thus, our results suggest that large amounts of the

324 excess $\mathrm{N}$ in soils amended annually with high rates of PS were lost by volatilization

325 and/or leaching.

326 Consistently with the results obtained in this work, Gutser et al. (2005) reported values

327 of NUE for mineral fertilization of $50-80 \%$, whereas the NUE values for PS were

328 generally smaller and more variable. Daudén and Quílez (2004) found levels of NUE of

$32930-40 \%$ for PS for an irrigated corn crop under Mediterranean conditions. Similarly,

330 Mooleki et al. (2002) reported values of NUE of $10-40 \%$ for liquid swine manure in a

331 field experiment with a canola-wheat-barley-canola rotation, and showed that the lower

332 the rate of liquid manure the lower the NUE. In a later work, Mooleki et al. (2004)

333 found values of NUE even lower for cattle manure (7-10\%).

334 In conclusion, our data indicate that the annual application of $30 \mathrm{~m}^{3} \mathrm{ha}^{-1}$ of PS

335 (equivalent to an average of $67 \mathrm{~kg} \mathrm{~N} \mathrm{ha}^{-1}$ ) results in barley yields similar to those

336 obtained with the traditional mineral fertilization in the study area. The addition of 60

$337 \mathrm{~m}^{3} \mathrm{ha}^{-1}$ yields slightly better results in terms of grain yield and permits to recycle larger 
amounts of PS; however, the $\mathrm{N}$ applied exceeds slightly the $\mathrm{N}$ removed by the barley crop, albeit safely adheres to European regulations for the use of $\mathrm{N}$ in agriculture (175 $\mathrm{kg} \mathrm{N} \mathrm{ha}^{-1}$ in zones draining into waters vulnerable to pollution from $\mathrm{N}$ compounds). The application of PS at rates higher than $60 \mathrm{~m}^{3} \mathrm{ha}^{-1}$ may result in better yields, but also in significantly lower $\mathrm{N}$ use efficiency and higher environmental impact. The high $\mathrm{N}$ relative to $\mathrm{C}$ content in PS and the Mediterranean climate may favor $\mathrm{N}$ mineralization over immobilization in PS-amended soils. Therefore, it is not advisable to apply PS at rates higher than those recommended for mineral $\mathrm{N}$ fertilizers. A good option could be to apply PS at low rates and, as suggested by Rogers et al. (2001) for other organic amendments, supply additional mineral $\mathrm{N}$ as needed based on fast soil $\mathrm{N}$ tests. The composition of PS depends on several factors such as type and physiological stage of the animals, time of sampling, and management conditions (Sánchez and González, 2005), and therefore should be analyzed prior to application.

\section{Acknowledgements}

We thank Laura Barrios for helping with statistical analyses. This work was supported by the Department of Agriculture and Environment of the Comunidad Autónoma de Castilla-La Mancha. D. Hernández is a researcher of the CSIC JAE-DOC program, cofunded by the European Social Fund.

\section{References}


Angás, P., Lampurlanés, J., Cantero-Martínez, C., 2006. Tillage and N fertilization effects on $\mathrm{N}$ dynamics and barley yield under semiarid Mediterranean conditions. Soil Tillage Res. 87, 59-71.

Bardgett, R.D., 2005. The Biology of Soil: A Community and Ecosystem Approach. Oxford University Press, New York.

Cadahía, C., Lucena, J.J., 1998. Diagnóstico de nutrición y recomendaciones de abonado, in: Cadahía, C. (Ed.), Fertirrigación. Cultivos Hortícolas y Ornamentales. Ediciones Mundi-Prensa, Madrid, Spain, pp. 173-246.

Daudén, A., Quílez, D., 2004. Pig slurry versus mineral fertilization on corn yield and nitrate leaching in a Mediterranean irrigated environment. Eur. J. Agron. 21, 7-19.

Díaz-Ambrona, C.H., Mínguez, M.I., 2001. Cereal-legume rotations in a Mediterranean environment: Biomass and yield production. Field Crop Res. 70, 139-151.

Díez, J.A., Hernaiz, P., Muñoz, M.J., De La Torre, A., Vallejo, A., 2004. Impact of pig slurry on soil properties, water salinization, nitrate leaching and crop yield in a fouryear experiment in Central Spain. Soil Use Manage. 20, 444-450.

Edmeades, D.C., 2003. The long-term effects of manures and fertilisers on soil productivity and quality: A review. Nutr. Cycl. Agroecosys. 66, 165-180.

Gutser, R., Ebertseder, T., Weber, A., Schraml, M., Schmidhalter, U., 2005. Short-term and residual availability of nitrogen after long-term application of organic fertilizers on arable land. J. Plant Nutr. Soil Sci. 168, 439-446.

Keeney, D. R., Nelson, D. W., 1982. Nitrogen-inorganic forms, in: Page, A. L., Miller, R. H., Keeney, D. R. (Eds.), Methods of Soil Analysis, Part 2. Chemical and Microbiological Properties. Agronomy Monograph No. 9. 2nd ed. ASA/CSSA/SSSA, Madison, WI, pp. 643-698.

López, L., 2010. Abonado de los dereales de invierno: trigo y cebada, in: Guía Práctica 
de la Fertilización Racional de los Cultivos en España. MARM (Ministerio de Medio Ambiente y Medio Rural y Marino), Secretaría General Técnica, Centro de Publicaciones, Madrid, Spain, pp. 123-133.

López, M., Grau, J.M., 2004. Metales Pesados, Materia Orgánica y Otros Parámetros de la Capa Superficial de los Suelos Agrícolas y de Pastos de la España Peninsular. INIA, Madrid, Spain.

MARM (Ministerio de Medio Ambiente y Medio Rural y Marino), 2010. Anuario de Estadística 2010. Secretaría General Técnica, Subdirección General de Estadística, Madrid, Spain.

Mengel, K., Kirkby, E., 2001. Principles of Plant Nutrition. Kluwer Academic Publishers, Dordrecht, The Netherlands.

Misselbrook, T.H., Nicholson, F.A., Chambers, B.J., 2005. Predicting ammonia losses following the application of livestock manure to land. Bioresour. Technol. 96, 159-168. Mooleki, S.P., Schoenau, J.J., Charles, J.L., Wen, G., 2004. Effect of rate, frequency and incorporation of feedlot cattle manure on soil nitrogen availability, crop performance and nitrogen use efficiency in east-central Saskatchewan. Can. J. Soil Sci. 84, 199-210.

Mooleki, S.P., Schoenau, J.J., Hultgreen, G., Wen, G., Charles, J.L., 2002. Effect of rate, frequency and method of liquid swine manure application on soil nitrogen availability, crop performance and $\mathrm{N}$ use efficiency in east-central Saskatchewan. Can. J. Soil Sci. 82, 457-467.

Nicholson, F.A., Chambers, B.J., Smith, K.A., Harrison, R., 1999. Spring applied organic manures as a source of nitrogen for cereal crops: Experiments using field scale equipment. J. Agr. Sci. 133, 353-363.

Pardo, G., Cavero, J., Aibar, J., Zaragoza, C., 2009. Nutrient evolution in soil and cereal 
413 yield under different fertilization type in dryland. Nutr. Cycl. Agroecosyst. 84, 267-279.

414 Petersen, J., 1996. Fertilization of spring barley by combination of pig slurry and

415 mineral nitrogen fertilizer. J. Agr. Sci. 127, 151-159.

416 Petersen, J., 2003. Weed:spring barley competition for applied nitrogen in pig slurry.

$417 \quad$ Weed Res. 43, 33-39.

418 Plaza, C., Senesi, N., García-Gil, J.C., Brunetti, G., D'Orazio, V., Polo, A., 2002.

419 Effects of pig slurry application on soils and soil humic acids. J. Agric. Food Chem. 50, $420 \quad 4867-4874$.

421 Plaza, C., García-Gil, J.C., Polo, A., 2005. Dynamics and model fitting of nitrogen 422 transformations in pig slurry amended soils. Commun. Soil Sci. Plant Anal. 36, 21374232152.

424 Rogers, B.F., Krogmann, U., Boyles, L.S., 2001. Nitrogen mineralization rates of soils 425 amended with non-traditional organic wastes. Soil Sci. 166, 353-363.

426 Sánchez, M., González, J.L., 2005. The fertilizer value of pig slurry. I. Values 427 depending on the type of operation. Bioresour. Technol. 96, 1117-1123.

428 Schröder, J.J., Jansen, A.G., Hilhorst, G.J., 2005. Long-term nitrogen supply from cattle 429 slurry. Soil Use Manage. 21, 196-204.

430 Schröder, J.J., Uenk, D., Hilhorst, G.J., 2007. Long-term nitrogen fertilizer replacement 431 value of cattle manures applied to cut grassland. Plant Soil 299, 83-99.

432 Soil Survey Staff, 2003. Keys to Soil Taxonomy. 9th ed. Natural Resources

433 Conservation Service. USDA, Washington.

434 Sørensen, P., Amato, M., 2002. Remineralisation and residual effects of $\mathrm{N}$ after 435 application of pig slurry to soil. Eur. J. Agron. 16, 81-95.

436 Thomsen, I.K., Sørensen, P., 2006. Interactions between soil organic matter level and 437 soil tillage in a growing crop: N mineralization and yield response. Soil Use Manage. 
$438 \quad 22,221-223$.

439 Vallejo, A., Díez López, J.A., López-Valdivia, L.M., Cartagena, M.C., Tarquis, A.,

440 Hernáiz, P.J., 2004. Denitrification from an irrigated soil dertilized with pig slurry under

441 Mediterranean conditions. Biol. Fertil. Soils 40, 93-100.

442 Yagüe, M.R., Quílez, D., 2010. Direct and residual response of wheat to swine slurry

443 application method. Nutr. Cycl. Agroecosys. 86, 161-174.

444 Zdruli, P., Jones, R.J.A., Montanarella, L., 2004. Organic Matter in the Soils of

445 Southern Europe. European Soil Bureau Technical Report, EUR 21083 EN. Office for

446 Official Publications of the European Communities, Luxembourg. 


\section{Research highlights}

- $\quad$ Pig slurry affects positively barley yield under Mediterranean conditions

- Low rates of pig slurry give grain yields similar to traditional mineral fertilization

- Low rates of pig slurry result in better $\mathrm{N}$ use efficiency

- High pig slurry rates may result in better yields but higher environmental impact

- Residual effects are evident up to 3 years after pig slurry application 


\section{FIGURE CAPTIONS}

Fig. 1. Monthly mean air temperature and monthly precipitation for the experimental period (1997-2003; bars). Historical patterns (1974-2004) are reported as solid lines.

Fig. 2. Scheme of the field plot experiment.

Fig. 3. Plant-available $\mathrm{N}$ content $\left(\mathrm{NH}_{4}{ }^{+}-\mathrm{N}\right.$ plus $\left.\mathrm{NO}_{3}{ }^{-}-\mathrm{N}\right)$ after harvest in the control (C) soil, minerally fertilized (MF) soil, and soils amended annually (A) or once at the beginning of the experiment (O) with $30,60,90,120$, and $150 \mathrm{~m}^{3} \mathrm{ha}^{-1}$ of pig slurry (PS30, PS60, PS90, PS120, and PS150, respectively). Error bars denote the standard error of the mean.

Fig. 4. Grain yield (a) and above-ground biomass (b) of barley grown on the control soil (C), minerally fertilized soil (MF), and soils amended with 30, 60, 90, 120, and $150 \mathrm{~m}^{3}$ $\mathrm{ha}^{-1}$ (PS30, PS60, PS90, PS120, and PS150, respectively) annually or once at the beginning of the experiment. Bars within the same chart with the same letter do not differ significantly according to the Tukey's HSD test at the 0.05 level.

Fig. 5. $\mathrm{N}$ content of grain (a) and $\mathrm{N}$ uptake (b) by barley grown on the control soil (C), minerally fertilized soil (MF) and soils amended with 30, 60, 90, 120, and $150 \mathrm{~m}^{3} \mathrm{ha}^{-1}$ (PS30, PS60, PS90, PS120, and PS150, respectively) annually or once at the beginning of the experiment. Bars within the same chart with the same letter do not differ significantly according to the Tukey's HSD test at the 0.05 level.

Fig. 6. Cumulative $\mathrm{N}$ uptake by barley crops harvested since 1998 until 2004 as affected by the cumulative $\mathrm{N}$ applied with annual mineral fertilization (MF) and 30, 60, 90, 120, and $150 \mathrm{~m}^{3} \mathrm{ha}^{-1} \mathrm{y}^{-1}$ of pig slurry (PS30, PS60, PS90, PS120, and PS150, respectively). Fig. 7. Cumulative $\mathrm{N}$ use efficiency (NUE), agronomic efficiency (AE), and mineralfertilizer equivalents (MFE) of mineral fertilizer (MF) and 30, 60, 90, 120, and $150 \mathrm{~m}^{3}$ $\mathrm{ha}^{-1}$ of pig slurry (PS30, PS60, PS90, PS120, and PS150, respectively) applied annually 
or once at the beginning of the experiment. Error bars denote the standard error of the mean. 

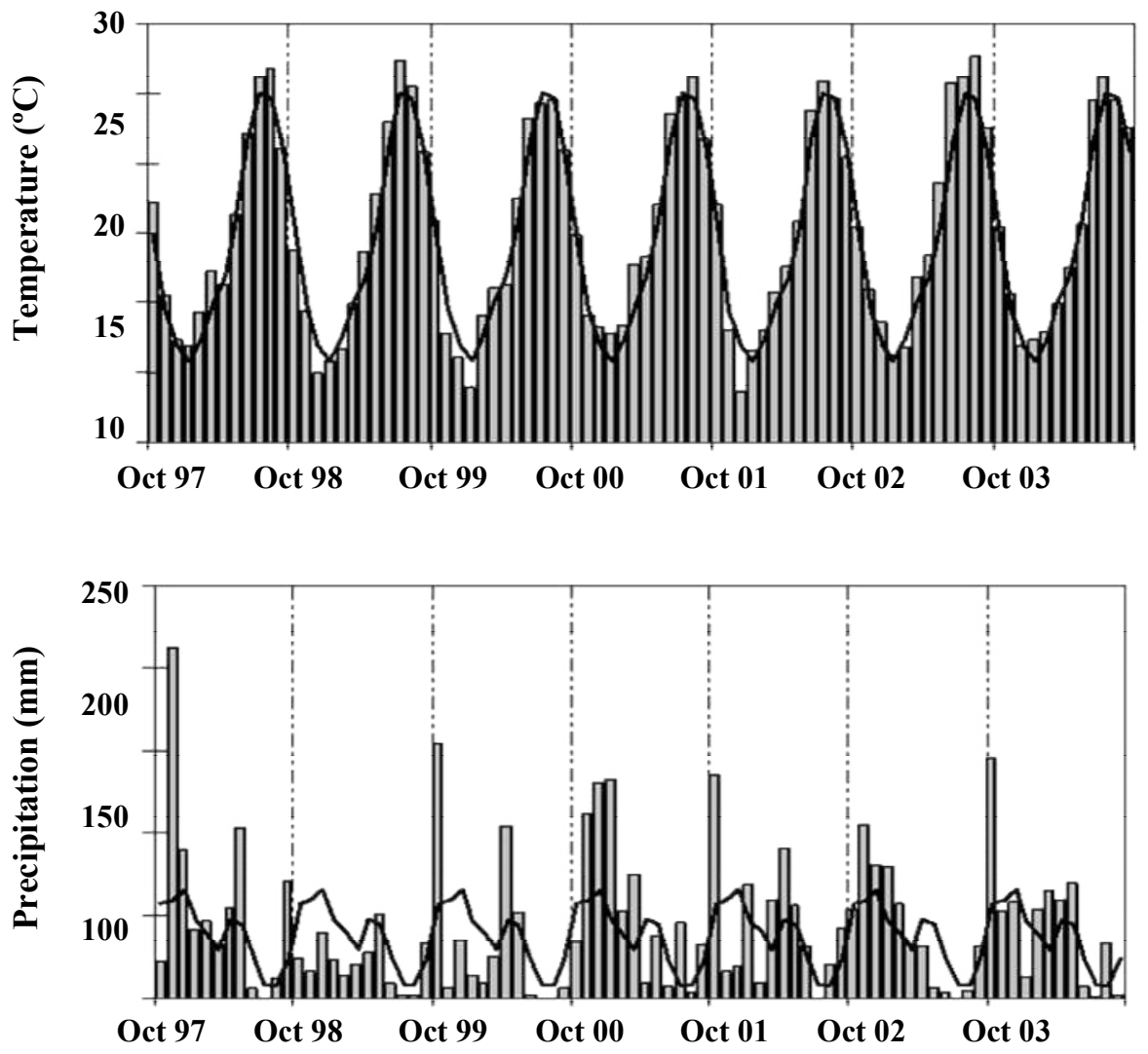


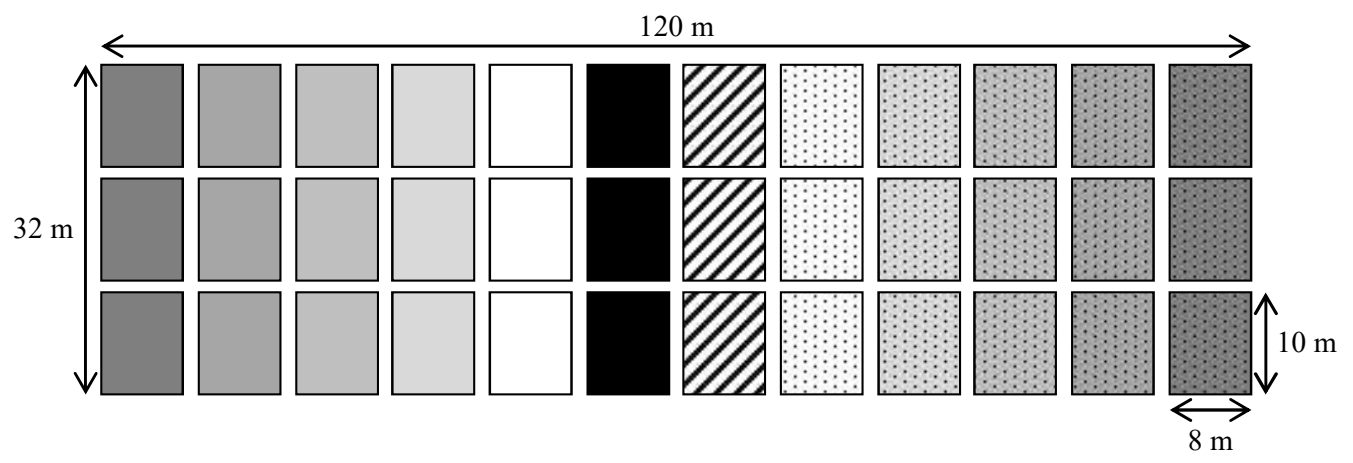

\section{ZZZ Control (C)}

Mineral fertilization (MF)

- $30 \mathrm{t} \mathrm{ha}^{-1}$ of pig slurry applied every year or only once at the beginning of the experiment (PS30)

- $60 \mathrm{t} \mathrm{ha}^{-1}$ of pig slurry applied every year or only once at the beginning of the experiment (PS60)

$\square 90 \mathrm{tha}^{-1}$ of pig slurry applied every year or only once at the beginning of the experiment (PS90)

$\square 120 \mathrm{tha}^{-1}$ of pig slurry applied every year or only once at the beginning of the experiment (PS120)

$\square 150 \mathrm{t} \mathrm{ha}^{-1}$ of pig slurry applied every year or only once at the beginning of the experiment (PS150) 


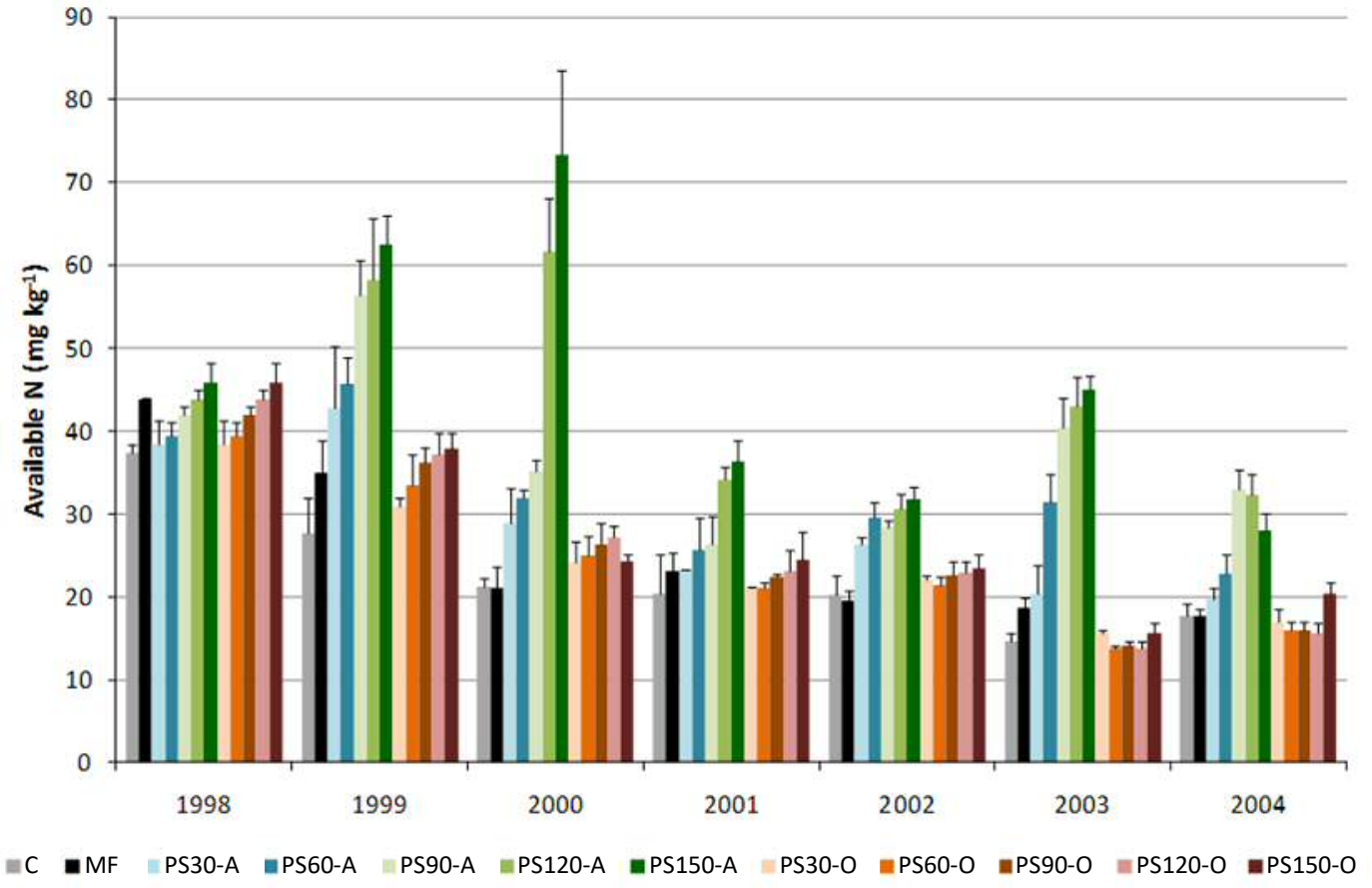


(a) Grain yield

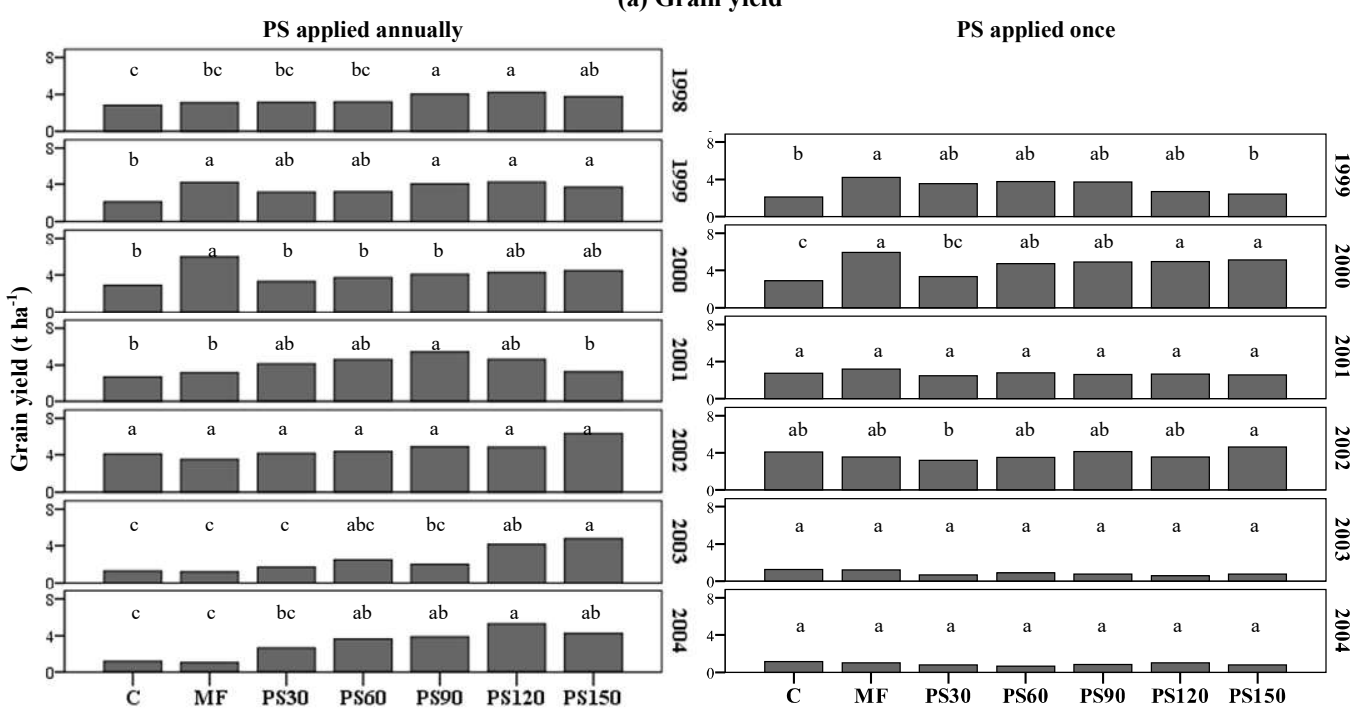

(b) Above-ground biomass

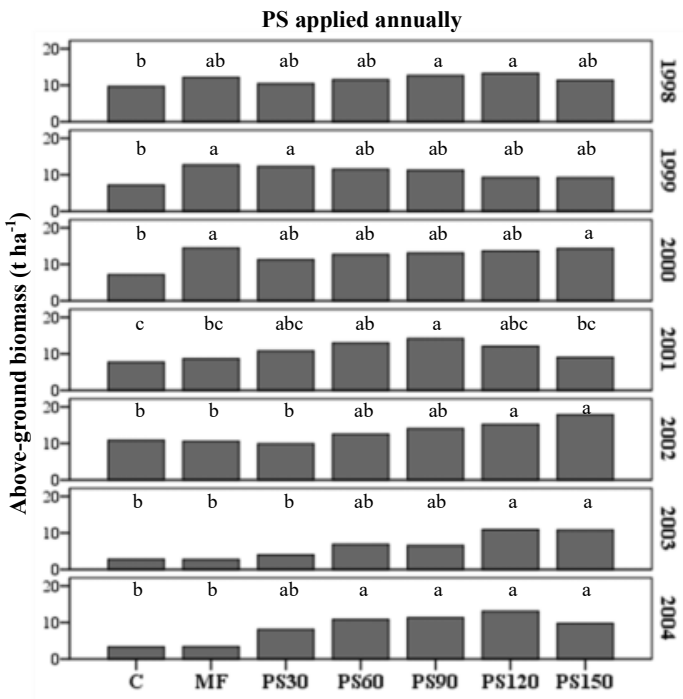

PS applied once

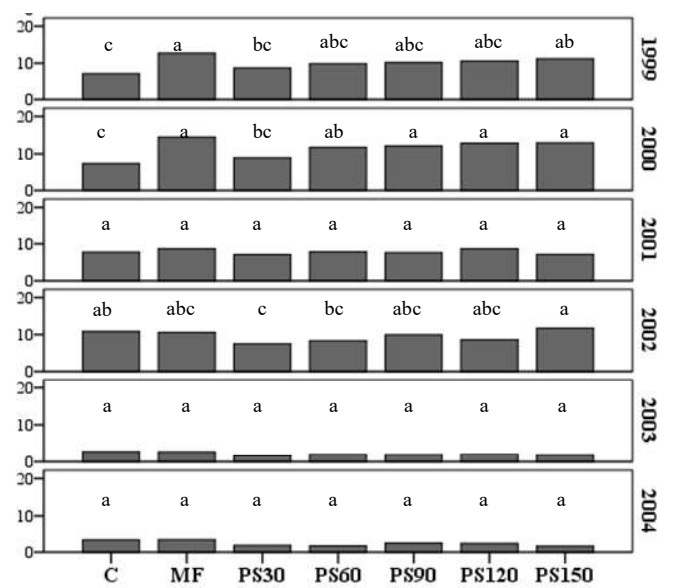


(a) $\mathrm{N}$ content of grain

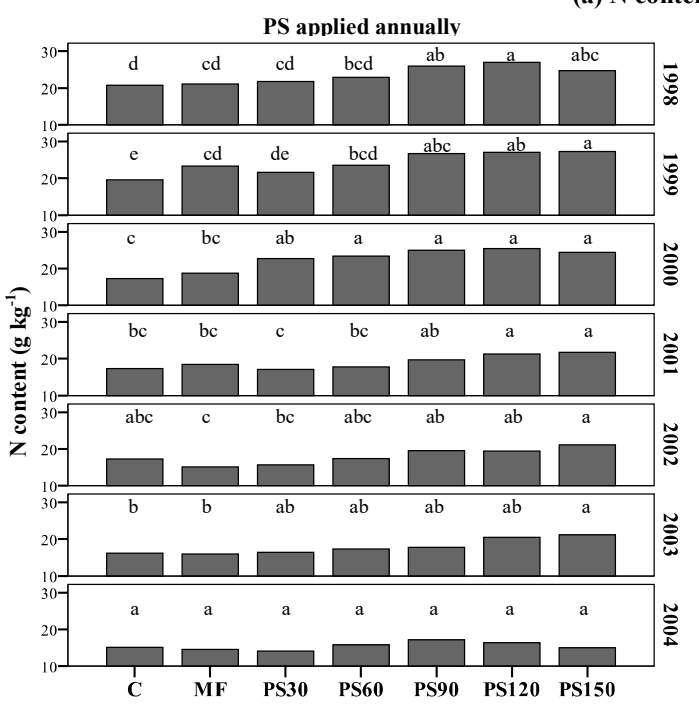

PS applied once

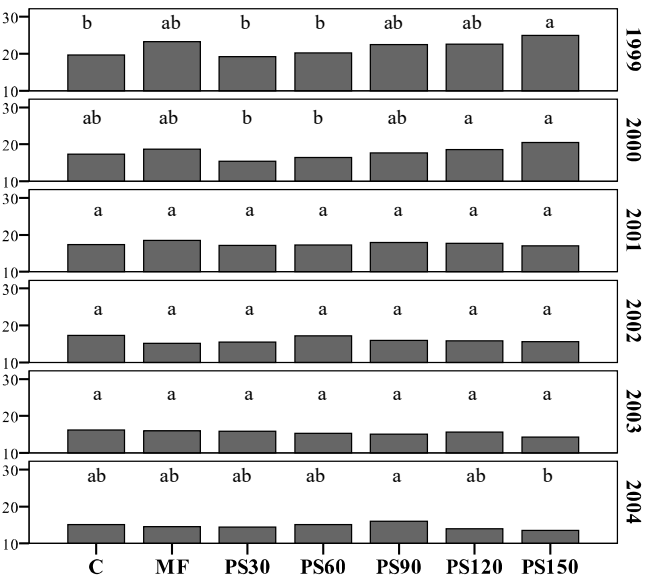

(b) $\mathrm{N}$ uptake by plants

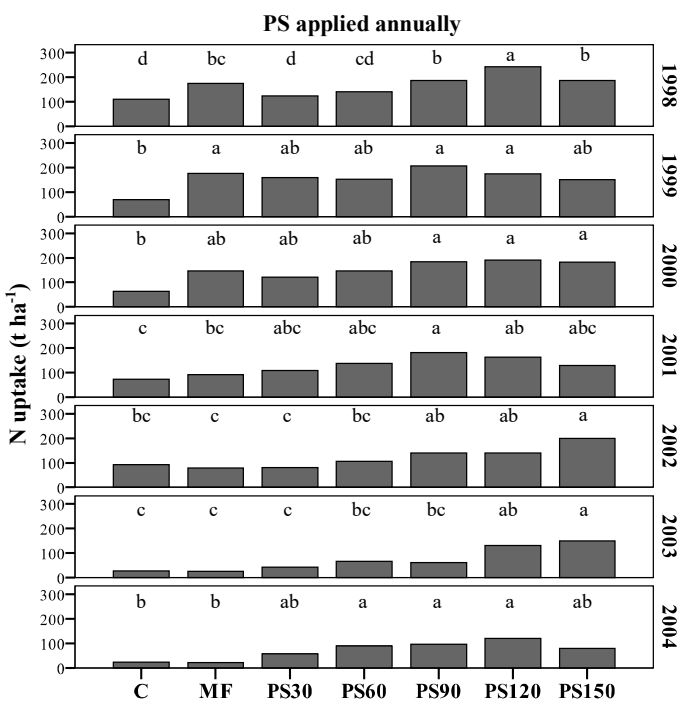

PS applied once

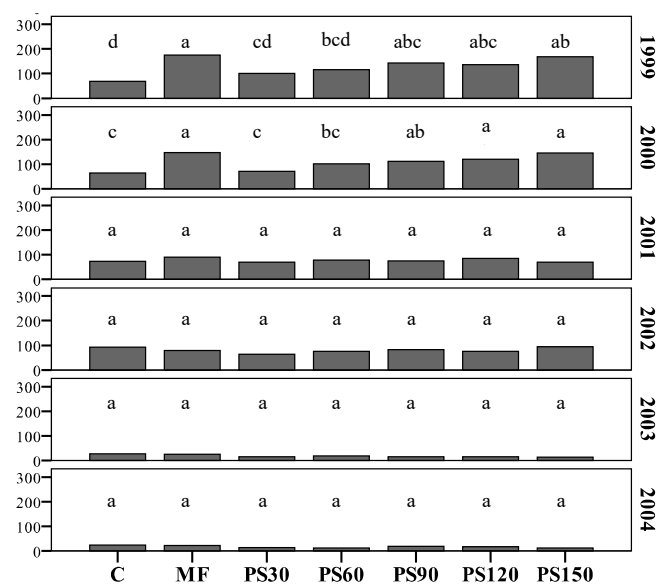



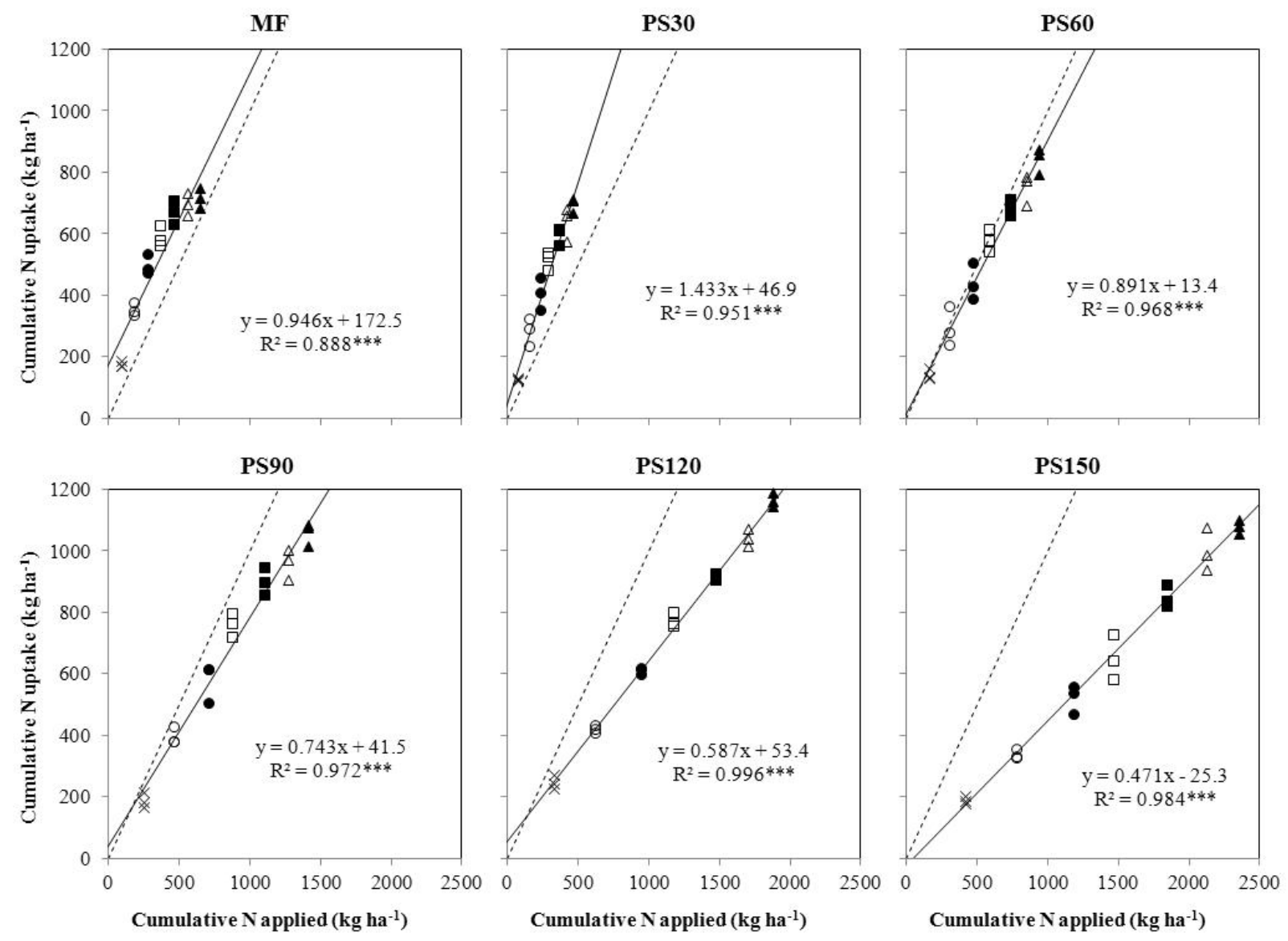

$\times 1998 \bigcirc 1999$ 

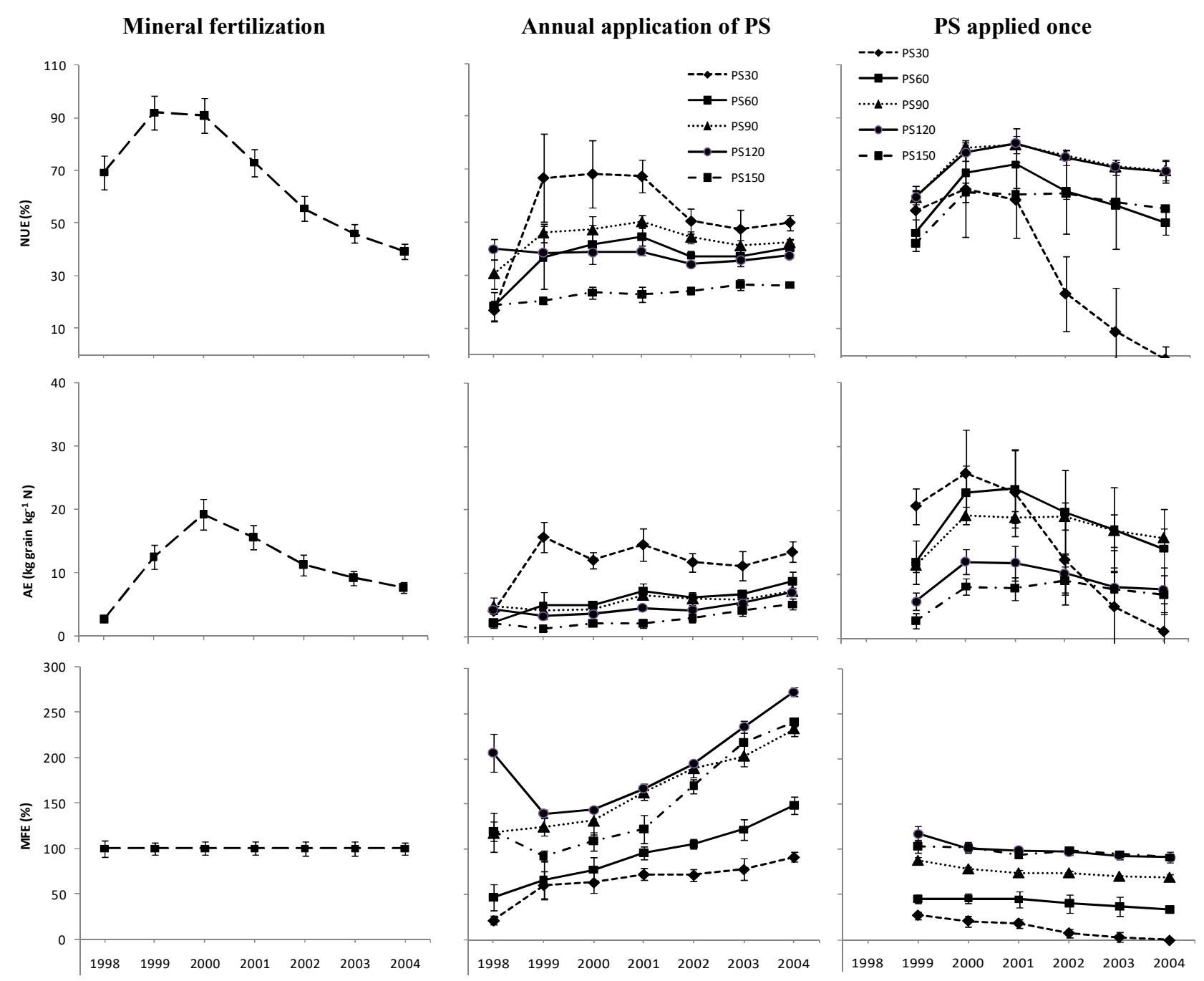
Table 1

Main properties of the pig slurry applied each year

\begin{tabular}{|c|c|c|c|c|c|c|c|}
\hline Property & 1997 & 1998 & 1999 & 2000 & 2001 & 2002 & 2003 \\
\hline Dry matter $\left(\mathrm{kg} \mathrm{m}^{-3}\right)$ & 20.0 & 15.8 & 26.7 & 12.4 & 14.5 & 12.6 & 10.0 \\
\hline $\mathrm{pH}$ & 7.5 & 7.6 & 7.2 & 7.4 & 7.4 & 7.8 & 7.8 \\
\hline $\mathrm{EC}\left(\mathrm{dS} \mathrm{m} \mathrm{m}^{-1}\right)$ & 16.4 & 16.9 & 14.5 & 12.6 & 10.8 & 12.7 & 10.9 \\
\hline TOC $\left(\mathrm{kg} \mathrm{m}^{-3}\right)$ & 7.3 & 5.7 & 11.2 & 5.0 & 5.4 & 3.1 & 2.7 \\
\hline Total $\mathrm{N}\left(\mathrm{kg} \mathrm{m}^{-3}\right)$ & 2.8 & 2.4 & 2.7 & 1.9 & 2.5 & 1.9 & 1.5 \\
\hline $\mathrm{NH}_{4}{ }^{+}-\mathrm{N}\left(\mathrm{kg} \mathrm{m}^{-3}\right)$ & 1.62 & 1.76 & 1.72 & 1.10 & 1.62 & 1.42 & 1.31 \\
\hline Total $\mathrm{P}\left(\mathrm{kg} \mathrm{m}^{-3}\right)$ & 0.53 & 0.39 & 0.52 & 0.306 & 0.23 & 0.19 & 0.12 \\
\hline Total $\mathrm{K}\left(\mathrm{kg} \mathrm{m}^{-3}\right)$ & 0.94 & 0.79 & 0.99 & 0.42 & 0.73 & 1.20 & 0.61 \\
\hline Total $\mathrm{Ca}\left(\mathrm{kg} \mathrm{m}^{-3}\right)$ & 0.58 & 0.39 & 0.43 & 0.20 & 0.23 & 0.27 & 0.25 \\
\hline
\end{tabular}

$\overline{\mathrm{EC}}$, electrical conductivity; TOC, total organic $\mathrm{C}$. 
Table 2

Total (1998-2004) above-ground biomass (AGB) and grain yield of barley grown on the control soil (C), soil amended with mineral fertilizer (MF), and soils amended with 30, 60, 90, 120, and $150 \mathrm{~m}^{3} \mathrm{ha}^{-1}$ (PS30, PS60, PS90, PS120, and PS150, respectively) annually (A) once at the beginning of the experiment $(\mathrm{O})$

\begin{tabular}{lcccc}
\hline & \multicolumn{2}{c}{ AGB $\left(\mathrm{t} \mathrm{ha}^{-1}\right)$} & \multicolumn{2}{c}{ Grain yield $\left(\mathrm{t} \mathrm{ha}^{-1}\right)$} \\
\hline Treatment & $\mathrm{A}$ & $\mathrm{O}$ & $\mathrm{A}$ & $\mathrm{O}$ \\
\hline C & $48.7 \mathrm{c}$ & $48.7 \mathrm{~b}$ & $17.1 \mathrm{~d}$ & $17.1 \mathrm{~b}$ \\
MF & $64.8 \mathrm{~b}$ & $64.8 \mathrm{a}$ & $22.1 \mathrm{~cd}$ & $22.1 \mathrm{a}$ \\
PS30 & $66.7 \mathrm{~b}$ & $35.9 \mathrm{c}$ & $22.3 \mathrm{~cd}$ & $14.0 \mathrm{~b}$ \\
PS60 & $79.0 \mathrm{ab}$ & $41.5 \mathrm{bc}$ & $25.2 \mathrm{bc}$ & $16.2 \mathrm{~b}$ \\
PS90 & $83.1 \mathrm{a}$ & $44.31 \mathrm{bc}$ & $28.4 \mathrm{ab}$ & $17.0 \mathrm{~b}$ \\
PS120 & $87.5 \mathrm{a}$ & $45.1 \mathrm{bc}$ & $31.7 \mathrm{a}$ & $15.4 \mathrm{~b}$ \\
PS150 & $82.4 \mathrm{a}$ & $46.5 \mathrm{~b}$ & $30.6 \mathrm{ab}$ & $16.3 \mathrm{~b}$ \\
\hline
\end{tabular}

Values followed by the same letter in the same column do not differ significantly according to the Tukey's HSD test at the 0.05 level. 